\title{
ANALISIS POST TO FOLLOWERS RATIO INSTAGRAM PADA 6 SEPATU SANDAL MERK LOKAL
}

\author{
I Putu Agus Surya Andika (19101041) \\ STIMIK STIKOM INDONESIA \\ aguskesiman772@gmail.com
}

\begin{abstract}
Information and Communication Technology is currently growing rapidly so that it can make it easier for everyone to exchange information with others through social media. One of the social media that currently has a big influence is Instagram. This study aims to find the ratios found on social media Instagram. These ratios can later be used to perform analyzes that can be measured mathematically. The research method used is exploratory to find the variables contained in Instagram. These variables will be juxtaposed to be tested for their relevance to find the relevant ratios used to assess the performance of an Instagram account. The results of this Instagram social media research show that 14 ratios can be used to assess, measure, and compare the credibility of an Instagram account. The discovery of this ratio implies that further researchers can conduct quantitative research in measuring, assessing, and comparing accounts contained on Instagram.
\end{abstract}

\begin{abstract}
ABSTRAK
Teknologi Informasi dan Komunikasi saat ini telah berkembang pesat sehingga mampu memudahkan setiap orang untuk bertukar informasi dengan orang lain melalui sosial media. Sosial media yang yang saat ini memiliki pengaruh besar salah satunya yaitu Instagram. Penelitian ini bertujuan untuk menemukan rasio - rasio yang terdapat pada sosial media Instagram. Rasio - rasio ini yang nantinya dapat digunakan untuk melakukan analisa yang dapat terukur secara matematis. Metode penelitian yang digunakan yaitu ekploratif untuk menemukan variabel - variabel yang terdapat pada Instagram. Variabel tersebut akan disandingkan untuk diuji relevansi nya sehingga menemukan rasio yang relevan digunakan menilai peforma sebuah akun Instagram yang. Hasil dari penelitian sosial media Instagram ini menunjukan bahwa terdapat 14 rasio yang dapat digunakan untuk menilai, mengukur serta membandingkan kredibilitas dari sebuah akun Instagram. Implikasi dari penemuan rasio ini adalah para peneliti selanjutnya dapat melakukan penelitian kuantitatif dalam mengukur, menilai serta membandingkan akun-akun yang terdapat pada instagram.
\end{abstract}

Keyword : Credibility Account Instagram ; Social Media Marketing ; Social Media Instagram ; Post to Followers Ratio ; Sepatu Sandal Merk Lokal 


\section{PENDAHULUAN}

Teknologi informasi dan komunikasi yang telah berkembang pesat mampu menghantarkan manusia untuk menciptakan bentuk baru cara berkomunikasi dan berinteraksi melalui media sosial. Sarana berkomunikasi menggunakan media sosial sangat berperan dalam aktifitas keseharian bersosial di masyarakat.

Teknologi informasi dan komunikasi dirasa penting keberadaannya oleh penggunanya, dimana salah satu tujuannya adalah untuk bertukar infomasi. Keberadaan sarana komunikasi ini memberikan dampak yang signifikan di berbagai bidang seperti, sosial, ekonomi, Pendidikan dan bidang lainnya. Komunikasi tidak hanya dapat di lakukan secara fisik, tetapi juga dapat di lakukan dengan menggunakan berbagai media sosial di dunia maya. Keunggulan layanan media sosial adalah memberikan ruang komunikasi dua arah antara konsumen-perusahaan dan konsumenkonsumen. Komunikasi dua arah ini memampukan konsumen untuk berpartispasi, kolaborasi dan berinteraksi, yang pada intinya konsumen tidak lagi objek tetapi subyek pemasaran.

Dengan pesatnya perkembangan teknologi media sosial, telah memberikan dampak terhadap situs - situs komunikasi, dari yang awalnya hanya sekedar email, dan chatting, sekarang sudah banyak jejaringan media sosial yang bisa digunakan sebagai alat komunikasi. Contohnya seperti, facebook, Instagram, twitter, Telegram, Snapchat.

Media sosial yang sangat diminati salah satunya adalah instagram. Instagram memiliki lebih dari 1 miliyar pengguna aktif [1]. Instagram adalah media sosial yang digunakan sebagai tempat menyebarkan dan berbagai informasi, berinteraksi dengan orang banyak, serta dapat mengenal lebih dekat dengan sesama pengguna .Instagram merupakan aplikasi berbagi foto yang memungkinkan pengguna mengambil foto, menerapkan filter digital, dan membagikannya ke berbagai layanan jejaring sosial [2].

Maraknya penggunaan Instagram membuat para peneliti ingin melakukan penilaian secara kualitatif terhadap akun - akun yang ada pada media sosial Instagram. Beberapa para peneliti telah melakukan penelitian yang terkait dengan penggunaan media sosial Instagram. Contohnya seperti penelitian Instagram sebagai media online shop dan juga sebagai media memamerkan gaya hidup atau kegiatan sehari-hari dari pemilik akun. Dalam hal ini peranan sistem informasi dalam Instagram adalah sebagai prediksi [3], [4], pendukung keputusan [5], dan keamanan [6].

Namun diantara beberapa penelitian yang sudah ada mengenai Instagram, belum ada peneliti yang meneliti tentang pencarian rasio - rasio yang dapat digunakan sebagai alat ukur dalam menilai berbagai aspek pada Instagram. Rasio - rasio ini yang nantinya dapat digunakan untuk melakukan analisa atau penelitian kuantitatif. Beberapa aspek yang dapat dinilai menggunakan rasio rasio hasil dari penelitian tersebut yaitu, yang pertama ingetsmen yang ada pada akun Instagram tersebut, apakah ingetsmen dari akun tersebut sudah bagus atau belum. Kedua, rasio - rasio ini juga bisa digunakan untuk mengukur kredibilitas dari akun Instagram tersebut. Dan yang ketiga, untuk menilai performa dari konten atau post yang posting pada akun Instagram tersebut. 


\section{TINJAUAN PUSTAKA}

Perkembangan bidang teknologi saat ini terjadi begitu pesat. Melalui perkembangan yang terjadi dari waktu ke waktu menimbulkan maraknya aplikasi - aplikasi serta platform media sosial yang bermunculan. Aplikasi yang sangat diminati oleh masyarakat saat ini diantaranya adalah TikTok, Instagram, Twitter, WhatsApp dan yang lain sebagainya. Seiring berjalannya waktu, aplikasi sosial media tersebut dapat menjadi candu bagi kalangan masyarakat. Tidak hanya kalangan remaja yang menggunakan aplikasi sosial media, orang tua bahkan anak-anak juga aktif menggunakan aplikasi sosial media tersebut.

Instagram merupakan salah satu bentuk hasil dari kemajuan internet dan tergolong salah satu media sosial yang cukup digandrungi oleh khalayak masa kini. Hal ini dapat dibuktikan dengan meningkatnya pengguna instagram pada setiap tahunnya. Terhitung pada April 2017 lalu, Instagram mengumumkan bahwa pengguna aktiv bulanannya telah mencapai kisaran 800 juta akun dan angka tersebut lebih banyak dibandingkan tahun sebelumnya (Yusuf, 2017). Berbeda dengan media sosial lainnya, instagram menitik beratkan kepada postingan foto dan video dari para penggunanya. Keunikan yang membuat instagram satu ini berbeda dengan media sosial pada umumnya. Apalagi, instagram seringkali memperbaharui sistemnya. Sejak kemunculannya pada tahun 2010 silam, instagram sering memperbarui fitur yang ada sehingga fiturnya lebih lengkap dan lebih menarik.

\section{METODE PENELITIAN}

Instagram merupakan social media yang berpengaruh karena memiliki pengguna yang besar. Pemangku kepentingan terhadap sebuah brand seperti perusahaan, artis, organisasi dan lainnya merasa sangat penting untuk menjaga identitas brand nya melalui instagram. Instagram disebutkan merupakan sebuah media sosial yang dapat digunakan untuk membangun sebuah brand melalui tampilan gambar-gambar. Peran instagram dalam industri makin dirasa penting karena tidak hanya brand yang dapat dibangun, aktifitas lainnya yang dapat dilakukan adalah implementasi marketing. Penelitian [7] menyatakan bahwa instagram dapat menimbulkan pengaruh sosial sehingga dapat meningkatkan penjualan produk.

Instagram yang semakin dirasakan memiliki kekuatan ataupun pengaruh dalam industri menimbulkan yaitu kualitas akun yang menentukan strata maupun kredibilitaspemilik akun. Penelitian [8] menyatakan bahwa kredibilitas selebgram (selebriti pada instagram) berpengaruh positif dan signifikan terhadap minat beli atau berbelanja pada instagram. Kredibilitas tidak hanya diperlukan pada industri, penelitian [9] menyatakan bahwa lembaga non profit seperti yayasan juga memerlukan kredibilitas untuk mendapatkan kepercayaan mendapatkan donasi melalui instagram.

Kredibilitas sebuah akun instagram merupakan sebuah hal yang penting untuk berbagai kepentingan. Kredibilitas dapat diukur dari peforma sebuah akun yang harus dapat diukur secara matematis. Dalam mengukur peforma diperlukan skala pengukuran yang akan tertuang dalam 
rasio-rasio. Skala pengukuran dibagai menjadi dua yaitu data kualitaitf dan data kuantitatif. Data kuantitatif dibagi menjadi dua yatiu; data diskrit/nominal dandata kontinum. Data kontinum dibagai menjadi tiga yaitu ordinal, interval dan ratio [10].

\subsection{Analisis Komunikasi}

Maraknya penggunaan instagram menimbulkan fenomena baru yang dimanfaatkan perusahaan ataupun perorangan untuk berinteraksi maupun berkomunikasi. Kondisi ini dimanfaatkan untuk meraih pengikut (followers) dengan cara melakukan inovasi, pemasaran dan berkomunikasi secara online. Setidaknya ada 4 katagori pengguna instagram yaitu :

1. Personal

2. Organisasi

3. Perusahaan

4. Pemerintah

Katagori Personal pada pengguna instagram yang dimaksud contohnya adalah : Artis, Tokoh, Pejabat publik, Selebgram, pekerja profesional, dan lain sebagainya. Katagori Organisasi pada pengguna instagram yang dimaksud contohnya adalah : Komunitas, Partai politik, NGO (Non-Governmental Organisation), NPO (nonprofit organization), dan lain sebagainya. Katagori Perusahaan pada pengguna instagram yang dimaksud adalah segala bentuk perusahaan yang bertujuan menghasilkan laba. Katagori Pemerintah pada pengguna instagram yang dimaksud adalah segala instansi pemerintahan sesuai dengan peraturan yang berlaku.

\subsection{Penelitian eksploratif}

Penelitian dengan tipe eksploratif ini akan meneliti seluruh katagori pengguna instagram dengan tujuan untuk memperdalam pengetahuan dan mencari ide-ide baru mengenai suatu gejala tertentu, menggambarkan fenomena sosial, dan menjelaskan bagaimana terjadinya suatu fenomena sosial. Penelitian eksploratis digunakan untuk merumuskan masalah secara lebih terperinci atau mengembangkan hipotesis bukan menguji hipotesis [11]. Penelitian ini bertujuan untuk menemukan variable-variabel pada instagram yang nantinya akan diformulasikan menjadi rasio-rasio. Akun instagram yang dapat dianalisis harus memenuhi syarat-syarat teknis pada settingan instagram untuk dapat dilakukan analisa yaitu :

1. Merupakan akun dengan status publik atau bukan privat sehingga data dapat diakses tanpa harus meminta ijin dari pemilik akun.

2. Kolom komentar tidak di non aktifkan (disable) sehingga kolom komentar mendefinisikan sebuah angka yang menunjukan jumlah komentar pada sebuah postingan.

3.

\subsection{Variabel}

Variabel adalah sesuatu yang memiliki nilai bervariasi dimana nilai tersebut dapat dijadikan dasar untuk 4 data yang berbeda seperti rasio, skala, ordinal, nominal dan internal. Penelitian ini bertujuan untuk menjadi acuan penelitian kuantitatif sehingga variable yang akan dianalisis adalah 
suatu objek yang memiliki nilai berupa angka sehingga dapat terhitung dalam proses menjadikan atau memformulasikannya sebagai rasio. Berikut adalah proses menemukan variabel pada instagram.

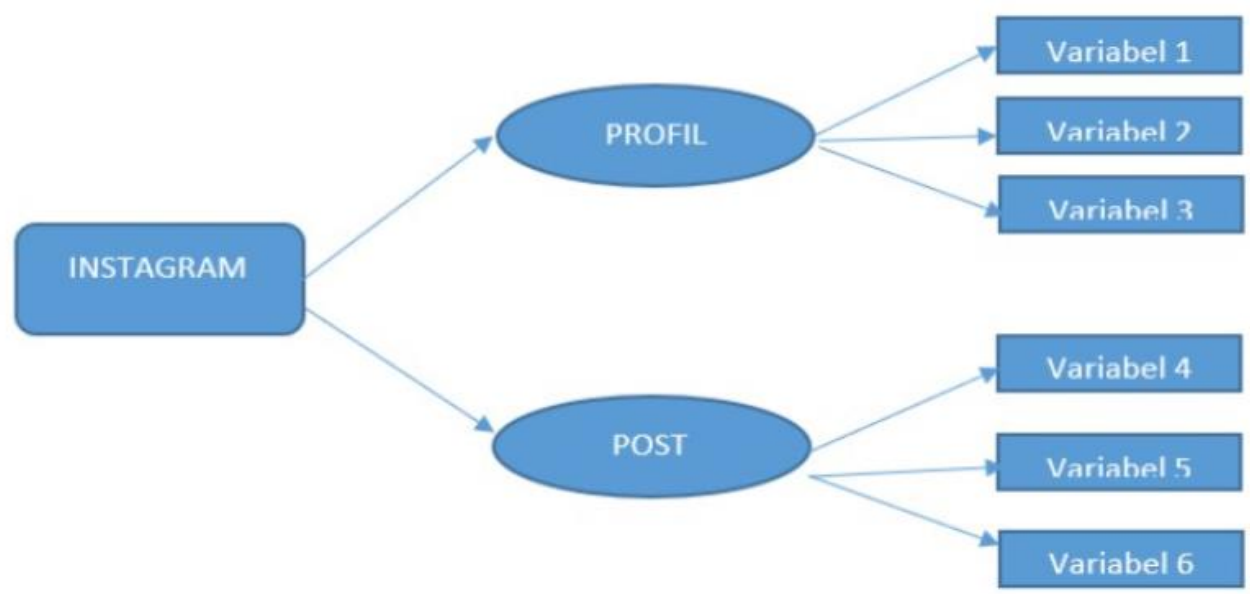

Gambar 1. Menemukan variabel pada Instagram

\subsection{Rasio}

Rasio merupakan perbandingan satu angka dengan angka lain yang membentuk suatu hubungan. Rasio merupakan suatu angka digambarkan dalam perbandingan suatu pola dengan pola lainnya serta dinyatakan dalam persentase [12]. Dalam menentukan sebuah rasio dibutuhkan minimal 2 variabel yang dibandingkan sehingga menghasilkan sebuah nilai yang hasil akhirnya dinyatakan dalam sebuah persentase. Dari seluruh variabel yang ditemukan akan dibandingkan dengan seluruh variabel yang di temukan lalu diuji relevansi nya sehingga dapat ditentukan apakah perbandingan atara kedua variabel dapat dikatagorikan sebagai rasio.

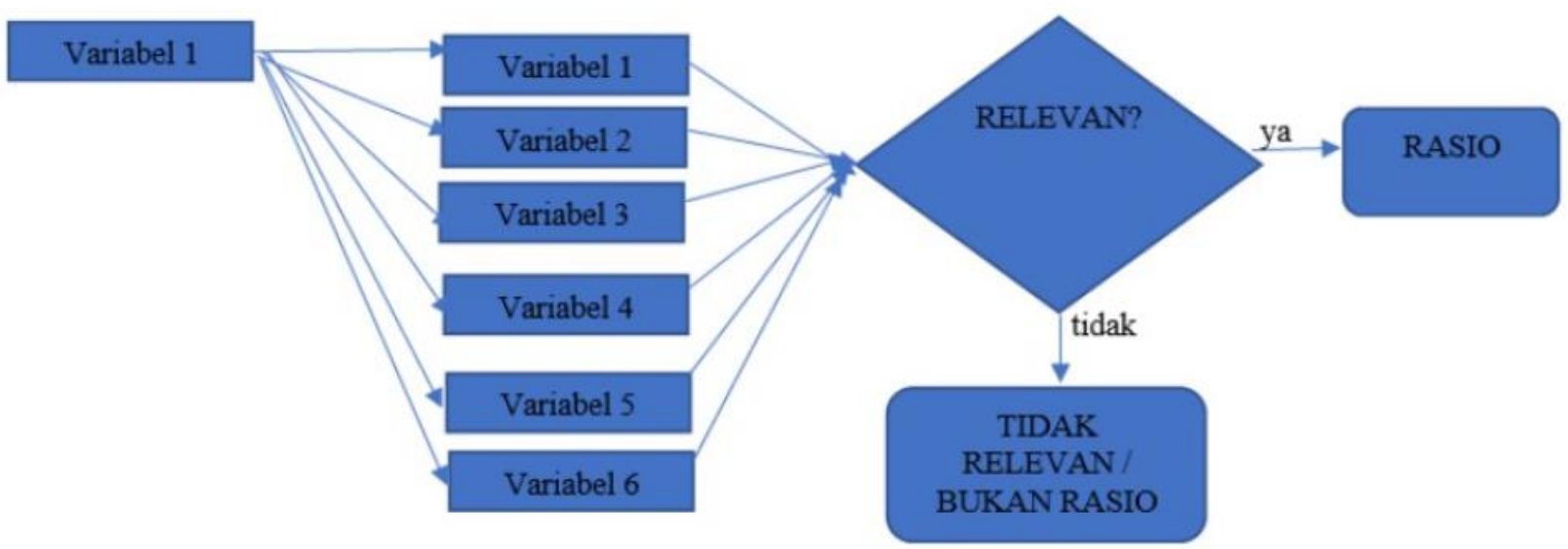

Gambar 2 Relevansi variabel terhadap rasio 
Pada gambar relevansi variabel terhadap rasio menunjukan variabel 1 yang dibandingkan dengan seluruh variabel lainnya sehingga menemukan 2 variabel yang relevan untuk dijadikan rasio. Setelah variabel satu selesai di analisa, dilanjutkan dengan variabel 2 seperti pada gambar berikut.

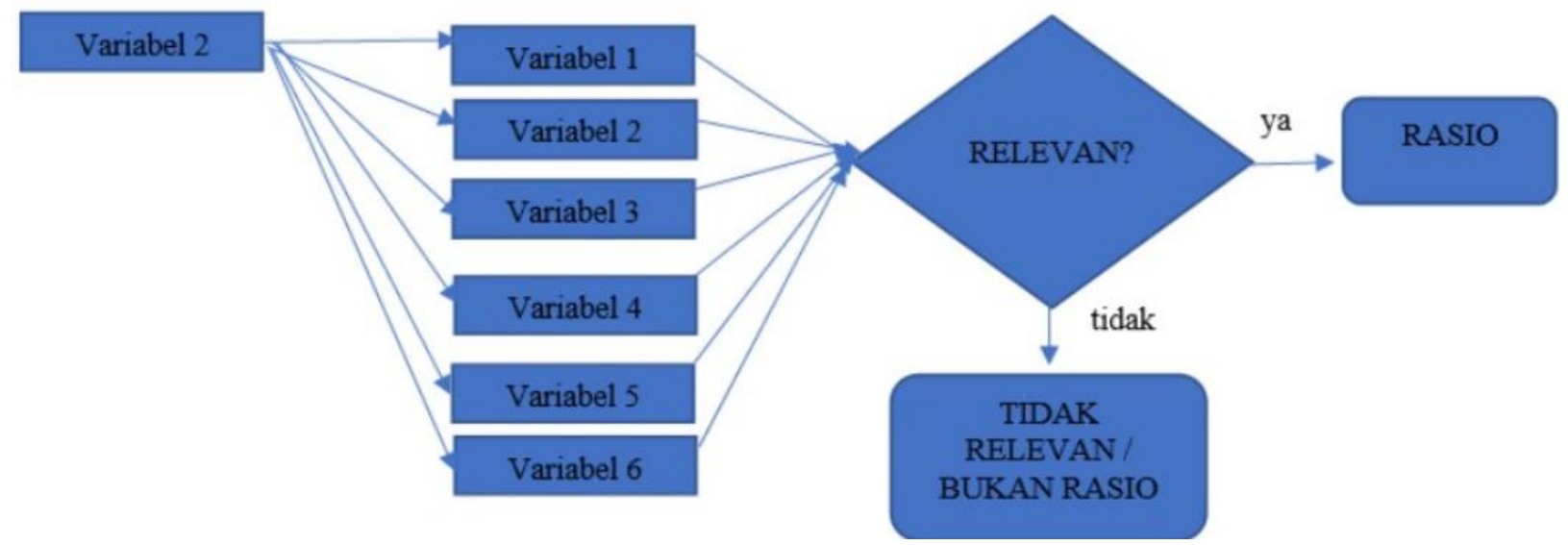

Gambar 3. Variable 2 dibandingkan dengan variabel lainnya

Pada gambar variabel 2 dibandingkan dengan seluruh variabel lainnya menunjukan perbandingan antara variabel 2 dengan seluruh variabel lainnya, sehingga menemukan 2 variabel yang relevan untuk dijadikan rasio. Setelah variabel dua selesai di analisa, dilanjutkan dengan variabel tiga, empat, lima dan seterusnya sampai dengan seluruh variabel dibandingkan dengan seluruh variabel.

Relevansi rasio ditunjukan dengan menganalisa pengaruh rasio tersebut terhadap penilian akun instagram yang di analisa. Rasio termasuk dalam katagori tidak relevan jika perbandingan antar 2 variabel terdapat kondisi sebagai sebagai berikut :

1. Perbandingan antar variabel yang sama.

2. Variabel pertama cenderung memiliki nilai yang lebih besar dibandingkan dengan variabel kedua.

3. Kedua variabel tidak dipengaruhi atau ditentukan oleh public.

4. Kedua variabel tidak pantas atau tidak tepat untuk dibandingkan.

\section{HASIL DAN PEMBAHASAN}

Karakteristik yang diterapkan di Instagram adalah dengan mengikuti (following) akun pengguna lainnya, atau memiliki pengikut (followers) pada akun pengguna tersebut. Kegunaan utama dari Instagram adalah sebagai tempat untuk mengunggah dan berbagi foto - foto atau video kepada pengguna lainnya. Pengguna Instagram juga dapat memberikan likes dan komentar di sebuah foto atau postingan dari akun pengguna lainnya.

Dengan melakukan analisis pada sebuah akun instagram, ditemukan variabel yang memiliki nilai berupa angka yaitu :

1. Profile:

- Posts

- Followers

- Following 
2. Post :

- Image Likes

- Image Comments

- Video Views

- Video Likes

- Video Comments

Akun Instagram dari 6 Brand Sepatu Sandal Lokal:

\section{Runo Project}

Instagram
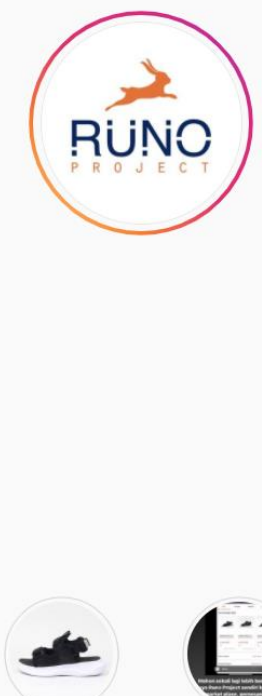

Produk Baru
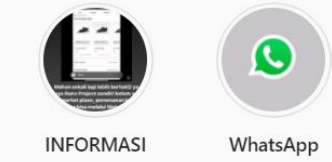

Gambar 1. Akun Instagram Runo Project

Sumber: https://www.instagram.com/runoproject/ (akses pada 21-10-2021) 


\section{TVF Footwear}

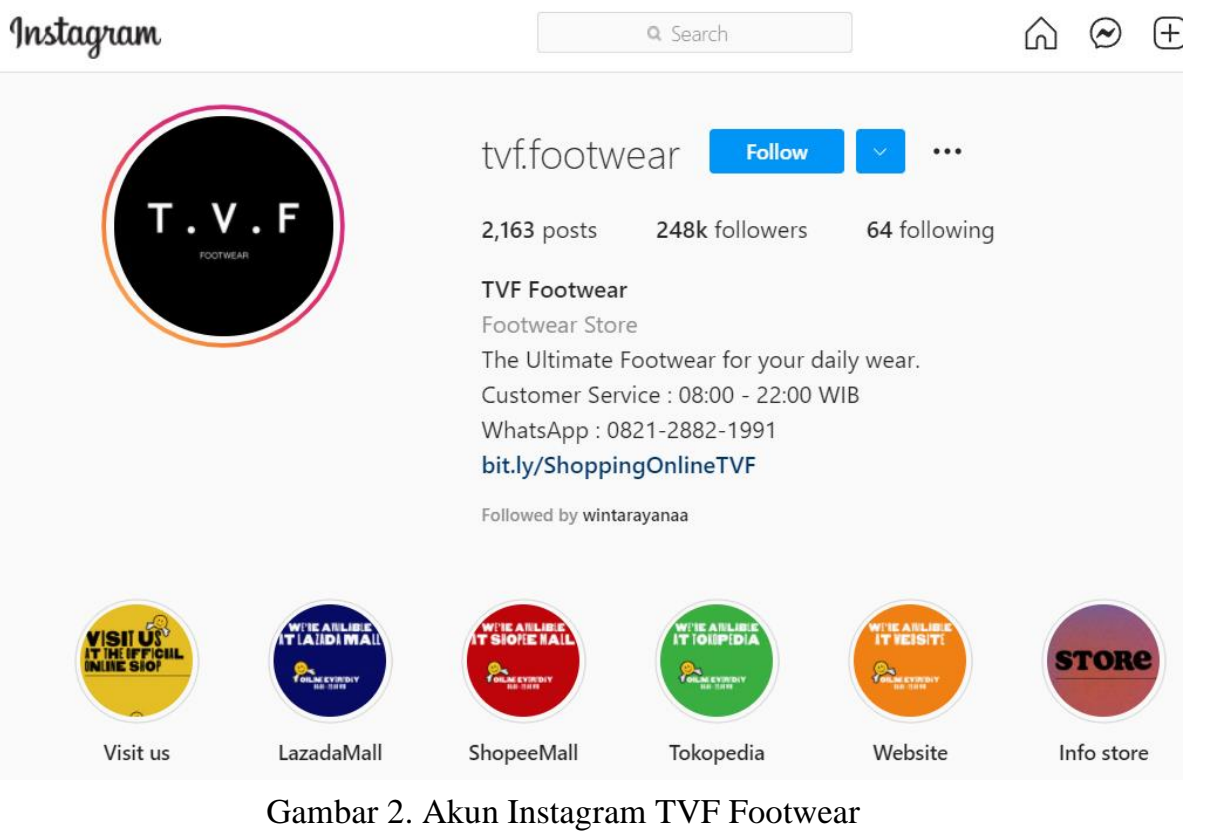

Sumber: https://www.instagram.com/tvf.footwear/ (akses pada 21-10-2021)

\section{Zoe Berlin}

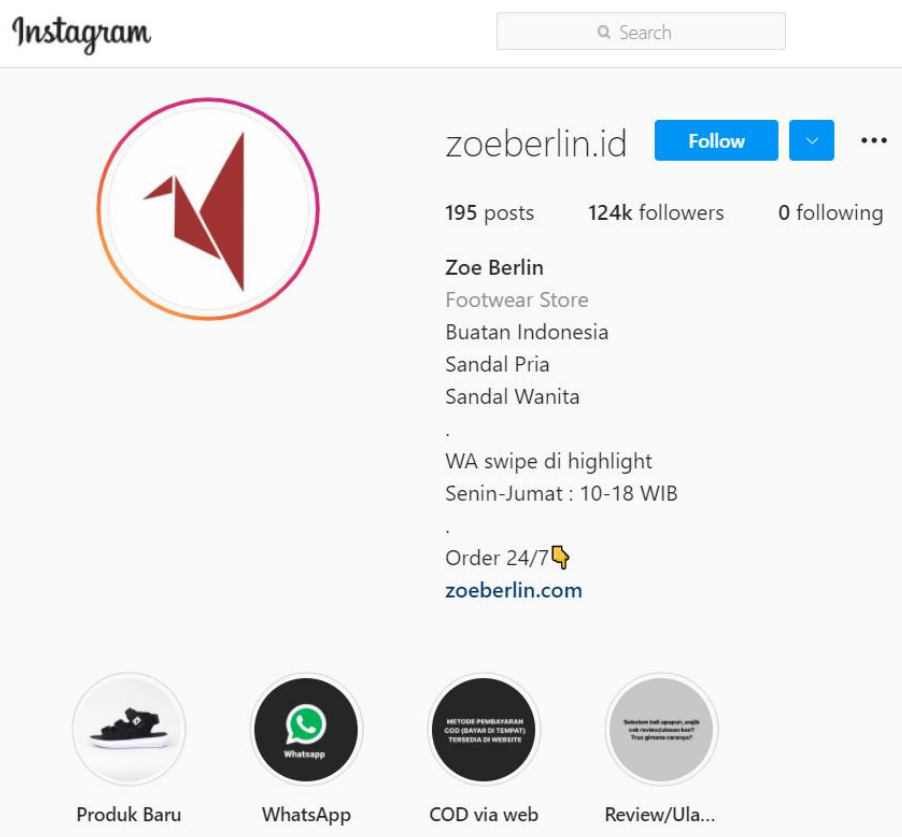

Gambar 3. Akun Instagram Zoe Berlin

Sumber: https://www.instagram.com/zoeberlin.id// (akses pada 21-10-2021) 


\section{Hi Jack Sandals}

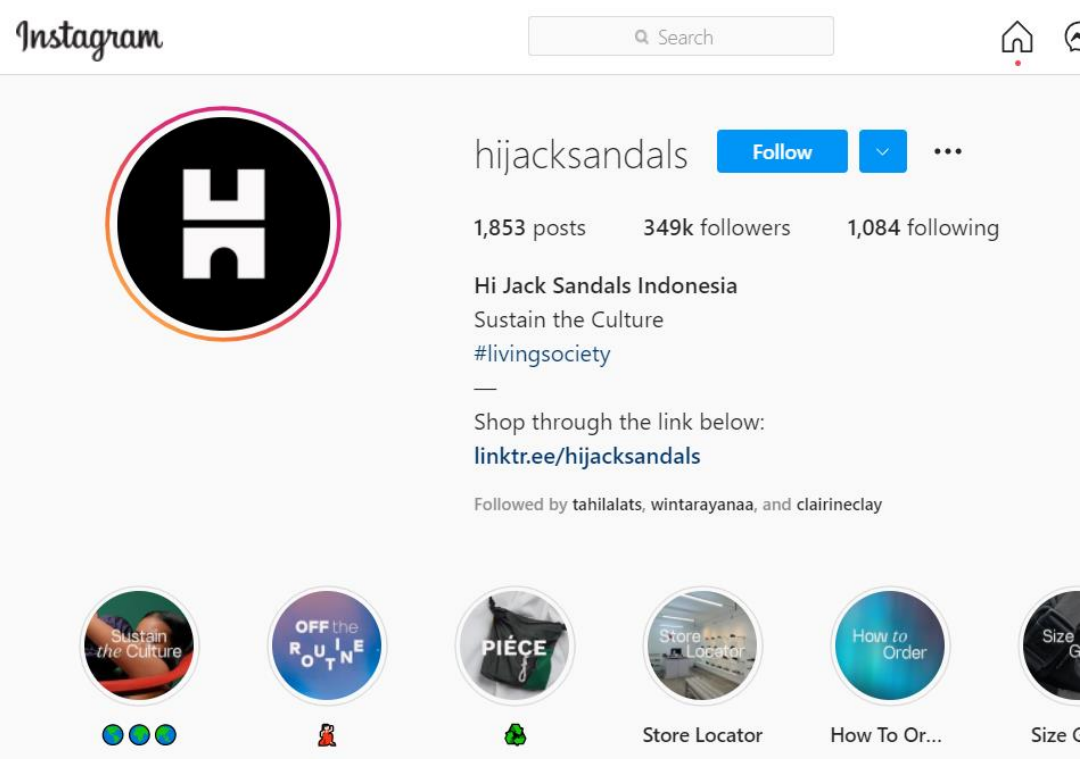

Gambar 4. Akun Instagram Hi Jack Sandals

Sumber: https://www.instagram.com/hijacksandals/ (akses pada 21-10-2021)

\section{Pvra}

Instagram
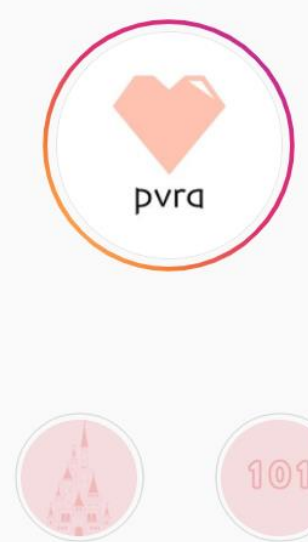

DISNEY X P...

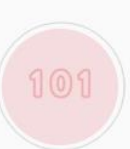

FACTS
Q Search

\section{pvra.official $* \quad$ Follow}

3,227 posts $\quad 285 \mathrm{k}$ followers

64 following

Your Sole Sister

Email: customerservice@pvra.co.id DISNEYXPVRA: Shop online now! 1 linktr.ee/pvra
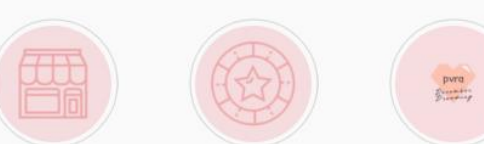

PVRALAND 


\section{Humblebarg}

Instagram
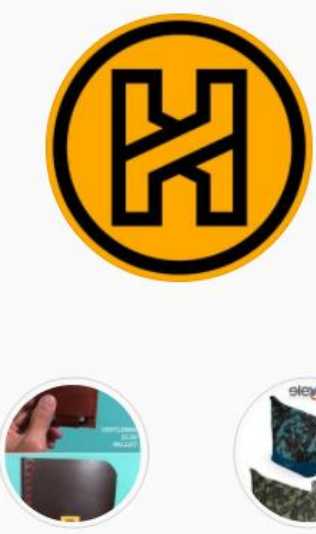

Leather

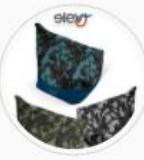

Camou Seri.. a. Search

\section{humblebrag.id Follow $\backsim \cdots$}

25 posts $\quad 357$ followers $\quad 222$ following

HUMBLEBRAG

a great plece for stylıн people

Gambar 6. Akun Instagram Humblebarg

Sumber: https://www.instagram.com/humblebrag.id/ (akses pada 21-10-2021)

Terdapat 8 variabel yang akan melalui proses analisis berikutnya yaitu perbandingan antar variabel dan pengujian relevansi antar dua perbandingan variabel. Adapun ke delapan variabel tersebut adalah :

1. Posts

2. Followers

3. Following

4. Image Likes

5. Image Comments

6. Video Views

7. Video Likes

8. Video Comments

Dari ketujuh variabel tersebut peneliti hanya fokus untuk menemukan hasil dari 2 variabel, yaitu :

1. Post

2. Followers

Dari kedua variabel tersebut kemudian dianalisa sehingga menemukan nilai rata-rata dari variabel post dan variabel followers. Untuk menghitung nilai rata-rata dari variabel post dan variabel followers yaitu dengan cara mengambil minimal 10 postingan kemudian di hitung sehingga menemukan nilai rata-rata dari masing-masing variabel. Berikut merupakan tabel nilai rata-rata dari masing-masing vendor smartphone di Indonesia, yaitu : 
Tabel 1. Analisa Nilai Rata-Rata Nilai Variabel Post dan Variabel Followers Akun Instagram Runo Project

\begin{tabular}{|c|c|c|}
\hline \multicolumn{3}{|l|}{ TVF Footwear } \\
\hline No & Post & Followers \\
\hline 1 & 2161 & 248.000 \\
\hline 2 & 2161 & 248.000 \\
\hline 3 & 2161 & 248.000 \\
\hline 4 & 2161 & 248.000 \\
\hline 5 & 2161 & 248.000 \\
\hline 6 & 2161 & 248.000 \\
\hline 7 & 2161 & 248.000 \\
\hline 8 & 2161 & 248.000 \\
\hline 9 & 2161 & 248.000 \\
\hline 10 & 2161 & 248.000 \\
\hline Total & $\mathbf{2 1 6 1}$ & $\mathbf{2 4 8 . 0 0 0}$ \\
\hline
\end{tabular}

Sumber: Pengolah Data Excel

Tabel 2. Analisa Nilai Rata-Rata Nilai Variabel Post dan Variabel Followers Akun Instagram TVF Footwear

\begin{tabular}{|c|c|c|}
\hline \multicolumn{3}{|l|}{ Runo Project } \\
\hline \multicolumn{1}{l|}{ No } & \multicolumn{1}{l|}{ Post } & Followers \\
\hline 1 & 734 & 167.000 \\
\hline 2 & 734 & 167.000 \\
\hline 3 & 734 & 167.000 \\
\hline 4 & 734 & 167.000 \\
\hline 5 & 734 & 167.000 \\
\hline 6 & 734 & 167.000 \\
\hline 7 & 734 & 167.000 \\
\hline 8 & 734 & 167.000 \\
\hline 9 & 734 & 167.000 \\
\hline 10 & 734 & 167.000 \\
\hline Total & 734 & 167.000 \\
\hline
\end{tabular}

Sumber: Pengolah Data Excel 
Tabel 3. Analisa Nilai Rata-Rata Nilai Variabel Post dan Variabel Followers Akun Instagram Zoe Berlin

\begin{tabular}{|c|c|c|}
\hline $\begin{array}{l}\text { Hi Jack } \\
\text { Sandals }\end{array}$ & & \\
\hline No & Post & Followers \\
\hline 1 & 1845 & 347.000 \\
\hline 2 & 1845 & 347.000 \\
\hline 3 & 1845 & 347.000 \\
\hline 4 & 1845 & 347.000 \\
\hline 5 & 1845 & 347.000 \\
\hline 6 & 1845 & 347.000 \\
\hline 7 & 1845 & 347.000 \\
\hline 8 & 1845 & 347.000 \\
\hline 9 & 1845 & 347.000 \\
\hline 10 & 1845 & 347.000 \\
\hline Total & $\mathbf{1 8 4 5}$ & $\mathbf{3 4 7 . 0 0 0}$ \\
\hline
\end{tabular}

Sumber: Pengolah Data Excel

Tabel 4. Analisa Nilai Rata-Rata Nilai Variabel Post dan Variabel Followers Akun Instagram Hi Jack Sandals

\begin{tabular}{|c|c|c|}
\hline \multicolumn{3}{|l|}{ Zoe Berlin } \\
\hline No & Post & Followers \\
\hline 1 & 195 & 124.000 \\
\hline 2 & 195 & 124.000 \\
\hline 3 & 195 & 124.000 \\
\hline 4 & 195 & 124.000 \\
\hline 5 & 195 & 124.000 \\
\hline 6 & 195 & 124.000 \\
\hline 7 & 195 & 124.000 \\
\hline 8 & 195 & 124.000 \\
\hline 9 & 195 & 124.000 \\
\hline 10 & 195 & 124.000 \\
\hline Total & 195 & $\mathbf{1 2 4 . 0 0 0}$ \\
\hline
\end{tabular}

Sumber: Pengolah Data Excel 
Tabel 5. Analisa Nilai Rata-Rata Nilai Variabel Post dan Variabel Followers Akun Instagram Pvra

\begin{tabular}{|c|c|c|}
\hline \multicolumn{1}{|l|}{ Pvra } & & \\
\hline No & Post & Followers \\
\hline 1 & 3220 & 285.000 \\
\hline 2 & 3220 & 285.000 \\
\hline 3 & 3220 & 285.000 \\
\hline 4 & 3220 & 285.000 \\
\hline 5 & 3220 & 285.000 \\
\hline 6 & 3220 & 285.000 \\
\hline 7 & 3220 & 285.000 \\
\hline 8 & 3220 & 285.000 \\
\hline 9 & 3220 & 285.000 \\
\hline 10 & 3220 & 285.000 \\
\hline Total & $\mathbf{3 2 2 0}$ & $\mathbf{2 8 5 . 0 0 0}$ \\
\hline
\end{tabular}

Sumber: Pengolah Data Excel

Tabel 6. Analisa Nilai Rata-Rata Nilai Variabel Post dan Variabel Followers Akun Instagram Humblebarg

\begin{tabular}{|c|c|c|}
\hline Humblebarg & & \\
\hline No & Post & Followers \\
\hline 1 & 25 & 356 \\
\hline 2 & 25 & 356 \\
\hline 3 & 25 & 356 \\
\hline 4 & 25 & 356 \\
\hline 5 & 25 & 356 \\
\hline 6 & 25 & 356 \\
\hline 7 & 25 & 356 \\
\hline 8 & 25 & 356 \\
\hline 9 & 25 & 356 \\
\hline 10 & 25 & 356 \\
\hline Total & $\mathbf{2 5}$ & $\mathbf{3 5 6}$ \\
\hline
\end{tabular}

Sumber: Pengolah Data Excel

Setelah menghitung nilai rata-rata tersebut, maka akan menemukan hasil akhir nilai rata-rata dari variabel video views dan followers 
Tabel 6. Nilai Variabel Pada 6 Sepatu Sandal Merk Lokal

\begin{tabular}{|l|r|r|r|r|r|r|}
\hline Variable & Hi Jack Sandals & Zoe Berlin & \multicolumn{1}{c|}{ Pvra } & Runo Project & TVF Footwear & Humblebarg \\
\hline Post & 1845 & 195 & 3220 & 734 & 2161 & 25 \\
\hline Followers & 347.000 & 124.000 & 285.000 & 167.000 & 248.000 & 356 \\
\hline
\end{tabular}

Sumber: Pengolah Data Excel

Pada akun Instagram terdapat 14 rasio yang relevan digunakan untuk mengukur kredibilitas pada masing-masing akun. Namun pada penelitian kali ini hanya berfokus untuk menghitung Post to Followers Ratio. Untuk menghitung kredibilitas dari masing-masing akun Instagram setiap vendor smartphone, peneliti menghitung dengan cara : variabel 1 akan dibagi dengan variabel 2 , sehingga ditemukan hasil analisisa dari rasio tersebut.

Tabel 7. Hasil Perhitungan Rasio Akun Instagram

\begin{tabular}{|c|c|c|c|c|c|c|c|}
\hline \multicolumn{7}{|c|}{ Tabel Rasio } \\
\hline No & $\begin{array}{c}\text { Ratio } \\
\text { Sandals }\end{array}$ & Zoe Berlin & Pura & $\begin{array}{c}\text { Runo } \\
\text { Project }\end{array}$ & $\begin{array}{c}\text { TVF } \\
\text { Footwear }\end{array}$ & Humblebarg \\
\hline & $\begin{array}{c}\text { Post to Followers } \\
\text { Ratio }\end{array}$ & 0,005317003 & 0,001572581 & 0,011298246 & 0,00439521 & 0,00871371 & 0,070224719 \\
\hline
\end{tabular}

Rasio jumlah Post terhadap jumlah Followers. Rasio ini menunjukkan efektifitas konten yang diposting terhadap keinginan seseorang untuk mengikuti / follow akun tersebut. Semakin sedikit jumlah post maka konten yang dibuat semakin menarik bagi publik yang akhirnya mau menjadi followers. Kelemahan dari rasio ini adalah data yang dihasilkan memiliki potensi atau kemungkinan tidak dapat dibandingkan dengan akun lain karena pemilik akun dapat menghapus postingannya sehingga tentu perhitungan rasio yang dihasilkan akan menjadi berubah. Karakterisik dari rasio ini adalah semakin kecil angka rasio maka semakin baik performa dari sebuah akun instagram

Tabel 8. Nilai Rasio Akun Instagram 6 Sepatu Sandal Merk Lokal

\begin{tabular}{|c|c|c|c|c|c|}
\hline \multicolumn{7}{|c|}{ Tabel Peringkat } \\
\hline Hi Jack Sandals & Zoe Berlin & Pvra & Runo Project & TVF Footwear & Humblebarg \\
\hline 4 & 3 & 5 & 1 & 2 & 6 \\
\hline
\end{tabular}

Dari Tabel Nilai Rasio Akun Instagram 6 Sandal Sepatu Merk Lokal dapat simpulkan bahwa Humblebarg mendapatkan nilai tertinggi untuk rasio Post to Followers. Sedangkan akun Instagram Runo Project mendapatkan nilai terendah untuk rasio ini. Jadi, pada penelitian ini Humblebarg 
memiliki kredibilitas performa yang lebih baik dibandingkan dengan brand sepatu sandal lokal yang lainnya.

\section{KESIMPULAN}

Penelitian ini bertujuan untuk menemukan rasio dengan menguji relevansi 8 variabel. Penilaian kredibilitas sebuah akun instagram dapat dinilai dinilai dari peforma rasio-rasio yang ditemukan pada penelitian ini. Terdapat 14 rasio yang relevan yang dapat digunakan sebagai parameter penilaian peforma. Implikasi dari penemuan rasio ini adalah para peneliti selanjutnya dapat melakukan penelitian kuantitatif dalam mengukur, menilai serta membandingkan akun-akun yang terdapat pada instagram.

\section{DAFTAR PUSTAKA}

Buffer.com, "21 Top Social Media Sites to Consider for Your Brand -," 2020. .

W. Prihatiningsih, "Motif Penggunaan Media Sosial Instagram Di Kalangan Remaja," Communication, vol. 8, no. 1, p. 51, 2017, doi: 10.36080/comm.v8i1.651.

P. Sugiartawan and S. Hartati, "Time series data prediction using elman recurrent neural network on tourist visits in tanah lot tourism object," J. Sist. Inf. dan Komput. Terap. Indones., vol. 1, no. 1, pp. 314-320, 2019. [4]

P. Sugiartawan, A. A. J. P. Permana, and P. I. Prakoso, "Forecasting Kunjungan Wisatawan Dengan Long Short Term Memory (LSTM)," J. Sist. Inf. dan Komput. Terap. Indones., vol. 1, no. 1, pp. 43-52, 2018. [5]

I. Pratistha, I. P. A. Mahadewa, and P. Sugiartawan, "Sistem Pendukung Keputusan Kelompok Pemilihan e-commerce/marketplace menggunakan metode profile matching dan BORDA,” J. Sist. Inf. dan Komput. Terap. Indones., vol. 1, no. 1, pp. 13-24, 2018.

P. Riska, P. Sugiartawan, and I. Wiratama, "Sistem Keamanan Jaringan Komputer dan Data Dengan Menggunakan Metode Port Knocking," J. Sist. Inf. dan Komput. Terap. Indones., vol. 2, no. 1, pp. 53-64, 2018. [7]

L. X. Teo, H. K. Leng, and Y. X. P. Phua, "Marketing on Instagram: Social influence and image quality on perception of quality and purchase intention," Int. J. Sport. Mark. Spons., vol. 20, no. 2, pp. 321-332, May 2019, doi: 10.1108/IJSMS-04-2018-0028. [8]

M. A. Irpansyah, A. M. Ramdan, and R. D. M. Danial, "Kredibilitas dan Kekuatan Selebgram dalam Meningkatkan Minat Beli pada Toko Online di Instagram," J. Econ. Bussines Account., vol. 2, no. 2, pp. 2597-5234, Apr. 2019, doi: 10.31539/costing.v2i2.554. [9]

B. Auramaitri, "Pengaruh Kredibilitas Pesan Instagram Yayasan Cinta Anak Bangsa terhadap Keputusan Followers untuk Berdonasi," 2019. [10] 
D. Nana and H. Elin, "Memilih Metode Penelitian Yang Tepat: Bagi Penelitian Bidang Ilmu Manajemen,” J. Ilmu Manaj., vol. 5, no. 1, p. 288, 2018, [Online]. Available: https://jurnal.unigal.ac.id/index.php/ekonologi/article/view/1359. [11]

B. Mudjiyanto, “Tipe Penelitian Eksploratif Komunikasi,” J. Stud. Komun. dan Media, vol. 22, no. 1, p. 65, 2018, doi: 10.31445/jskm.2018.220105. [12]

A. R. Makkulau, "Pengaruh Rasio Keuangan Terhadap Financial Distress Pada Perusahaan Sektor Industri Dasar Dan Kimia Yang Terdaftar Di Bursa Efek Indonesia," Tangible J., vol. 5, no. 1, pp. 11-28, 2020, doi: 10.47221/tangible.v5i1.113. 